\title{
Free Standing Billboards in a Road Landscape: Their Visual Impact and Its Regulation Possibilities (Lithuanian Case)
}

\author{
Jūratė Kamičaitytė-Virbašiené $\dot{1}^{1}$ Ona Samuchoviené $\dot{2}^{2}$ \\ ${ }^{I}$ Kaunas University of Technology, Faculty of Civil Engineering and Architecture, Kaunas, Lithuania \\ ${ }^{2} U A B$ Infraplanas, Kaunas, Lithuania
}

cross $^{\text {ref }}$ http://dx.doi.org/10.5755/j01.erem.66.4.5320

(Received in September, 2013; accepted in December, 2013)

\begin{abstract}
Free standing billboards have a significant negative visual impact on the landscape. In the majority of foreign countries construction of free standing billboards is regulated by various legal instruments, guidelines and control manuals. In Lithuania the construction of free standing billboards considering their visual impact is poorly regulated by juridical and spatial planning means. Taking this situation into account the paper aims to review main problems of regulating free standing billboards construction in Lithuania, to assess their impact on the landscape, to present foreign experience in solving these problems and to provide methodological guidelines for regulation of free standing billboards construction considering their visual impact. The proposed stages of the assessment of free standing billboards visual impact are the following: analysis of the landscape spatial structure designating visual spaces perceived from separate road sections, analysis of the possibilities of free standing billboards layout designating visual spaces protected from free standing billboards construction and visual spaces as free standing billboards construction areas, establishment of the possible visual contrast level of free standing billboards and establishment of free standing billboards location in a visual space and a visual contrast character according to the SID theory and results of the visual space evaluation according to the criteria of vitality, complexity, compositional harmony, expressivity, uniqueness, functionality and meaningfulness.
\end{abstract}

Keywords: free standing billboards, landscape, visual impact assessment

\section{Introduction}

In most of foreign countries the construction of free standing billboards (FSBs) is regulated by various legal instruments, guidelines and control manuals. Restrictions imposed on FSB are established considering road category, road engineering elements, road environment and the area where the road is paved. Restrictions are based on the negative effects of outdoor advertising on the road users (e.g. distraction, or disorientation), and a negative impact on the landscape (i.e. landscape visual pollution).

In Lithuania the construction of FSBs is prohibited in road lanes and protection zones (LR Keliu... 2002). Installation of outdoor advertisements in the objects of cultural heritage and their areas and protection zones as well as protected areas is permitted only in cases prescribed by the Laws of
Lithuania having obtained consent from the authorities responsible for the protection of the mentioned objects and territories (LR Reklamos... 2013). In other ways the construction of FSB is practically out of control, there are no regulating documents determining the construction and installation conditions for FSBs in Lithuania. Therefore, FSBs on Lithuanian roadsides become an aesthetic problem of the landscape.

Development of outdoor advertising in conditions of free market economy is the process hard to control. However as Lithuanian and foreign experience shows, regulation of the layout and its visual impact is essential for preservation and enhancement of visual quality and identity of the landscape. To achieve this goal in 2013 the 
Conception of Construction of FSB close to Roads and Railways was prepared. Work developer was the Ministry of the Environment of Lithuania. The conception is based on the present state analysis, environmental impact assessment and foreign experience. It provides both an overview of the possibilities of FSB construction that have no significant impact on the aesthetic quality of the landscape visual spaces, and recommendations for the regulation of FSB construction (for FSB size and shape, distance from the road, purposes of the territories in which FSB can be constructed etc).

The aim of this paper is to review major problems facing the regulation of FSB construction and to assess their impact on the landscape, to present foreign experience in solving these problems and to provide methodological guidelines for regulation of FSBs construction taking into account their visual impact.

\section{Methods}

In order to receive the pursued results we carried out literature analysis and field survey. While analysing the concerned literature we explored the issues of the regulation of outdoor advertisement construction in Denmark, Finland, Scotland, Republic of South Africa, Australia and the others, reviewed the UK and the USA experience in the fields of visual impact assessment and the Lithuanian legal basis of outdoor advertisement regulation and environmental impact assessment. When performing the field survey we assessed the FSBs impact on different functional and visual types of the landscape, evaluated the FSBs layout and its character, density, quantity, sizes and shapes. This allowed us to clear out major problems of the FSBs construction regulation and possibilities of their solution. Using the method of logical analogy and considering peculiarities of Lithuanian landscape, we proposed methodological guidelines for FSB visual impact assessment.

\section{Results and Discussion}

\subsection{Regulation of free standing billboards construction and their visual impact on Lithuanian landscape: present state}

\section{Legal regulation of FSB construction}

The use of FSBs for advertising mostly increased in 2006, especially along highway A1 Vilnius - Kaunas - Klaipeda. This is explained by exceptionally high daily average car traffic intensity, which is approximately 6 times higher than that in other Lithuanian state roads.

According to the Advertising Act of the Republic of Lithuania (LR Reklamos..., 2013) installation of advertisements on the roads, above the roads and on the road lanes and protection zones is prohibited. As a result, advertising service providers, in order not to lose advertising consumers, began to install huge FSBs beyond the limits of the road protection zones. The Roads Act of the Republic of Lithuania (LR Kelių... 2002) deals with the prohibition on the construction of FSBs on road lanes and protection zones whose width depends on the road categories. Installation of outdoor advertisements on the objects of cultural heritage and their areas and protection zones is permitted only in cases prescribed by the Act of Immovable Cultural Heritage (LR Reklamos... 2013) after receiving consent from the authorities responsible for the protection of the mentioned objects. In protected areas installation of outdoor advertisements is possible only in agreement with the protected area administration, or the regional department of environmental protection. Advertisements can be installed on the land, buildings or other objects with the consent of their owner and the permission of the municipal authorities for the construction of FSB. In other aspects, such as FSB size and shape, distance from the road, territories in which FSB can be constructed etc, the construction of FSB is not regulated - there are no regulating documents determining construction and installation conditions for FSB in Lithuania. Only a few municipalities have issued additional advertising regulatory measures.

Advertising businessmen are deliberately seeking the subjects to attract road users' attention. Their objectives implementing their economic interests not only lead to safety risk on the road but also directly affect and shape the road landscape (Studija dèl išorinès vaizdinès..., 2005). Therefore, the construction of FSB needs to be assessed considering their visual impact on the landscape.

In accordance with the theoretical transactions of Lithuanian scientists it can be stated that visual contrast analysis assessing an object visual impact on the environment should consist of visibility analysis of the object and visual contrast rating (positive or negative contrast, contrast level etc) according to the relation of visual characteristics of the analysed object and contextual environment: size, shape, colour, tone, facture and texture (Kamičaitytè-Virbašienè 2003). However, results of the theoretical transactions are slightly used in the legal documents and practical spatial planning activities. Referring to the Regulation of the Environmental Impact Assessment Program and Report Preparation (Dèl poveikio aplinkai vertinimo..., 2005) an impact of the proposed economic activity on the landscape is to be assessed and mitigation measures are to be provided. The landscape has to be analysed in the following aspects: type, regionalism, mosaic structure, diversity, geomorphological characteristics, hydrographical network and forest cover. Among other requirements, the impact on the aesthetic value of the landscape has to be identified, and the aesthetic ecologic potential has to be increased and the other measures have to be taken to reduce the impact. But there is no definition what the visual impact is, what the criteria are on the basis of which the impact has to be assessed etc. One of the necessary schemes is the evaluation of 
landscape aesthetic resources and an impact assessment scheme, whereupon the principles according to which it has to be drafted are implicit.

\section{FSB impact on the landscape}

In 2012, using orthophoto-maps and performing the field survey, FSBs were inventoried (setting their coordinates) on the main highways of Lithuania: A1 Vilnius-Kaunas-Klaipėda and A2 Vilnius-Panevėžys (Figure 1). There are 198 FSBs located at the analysed highways. Several FSBs are located at the other Lithuanian state roads too. The highest FSBs density is close to road A1 between Vilnius and Kaunas (length $100 \mathrm{~km}$ ). There are 116 FSBs. The second road sector according to FSBs density is between Kaunas and Klaipèda (length $200 \mathrm{~km}$ ). There are 66 FSBs. The third sector is between Vilnius and Panevėžys (length $130 \mathrm{~km}$ ) in which only 16 FSBs are located.

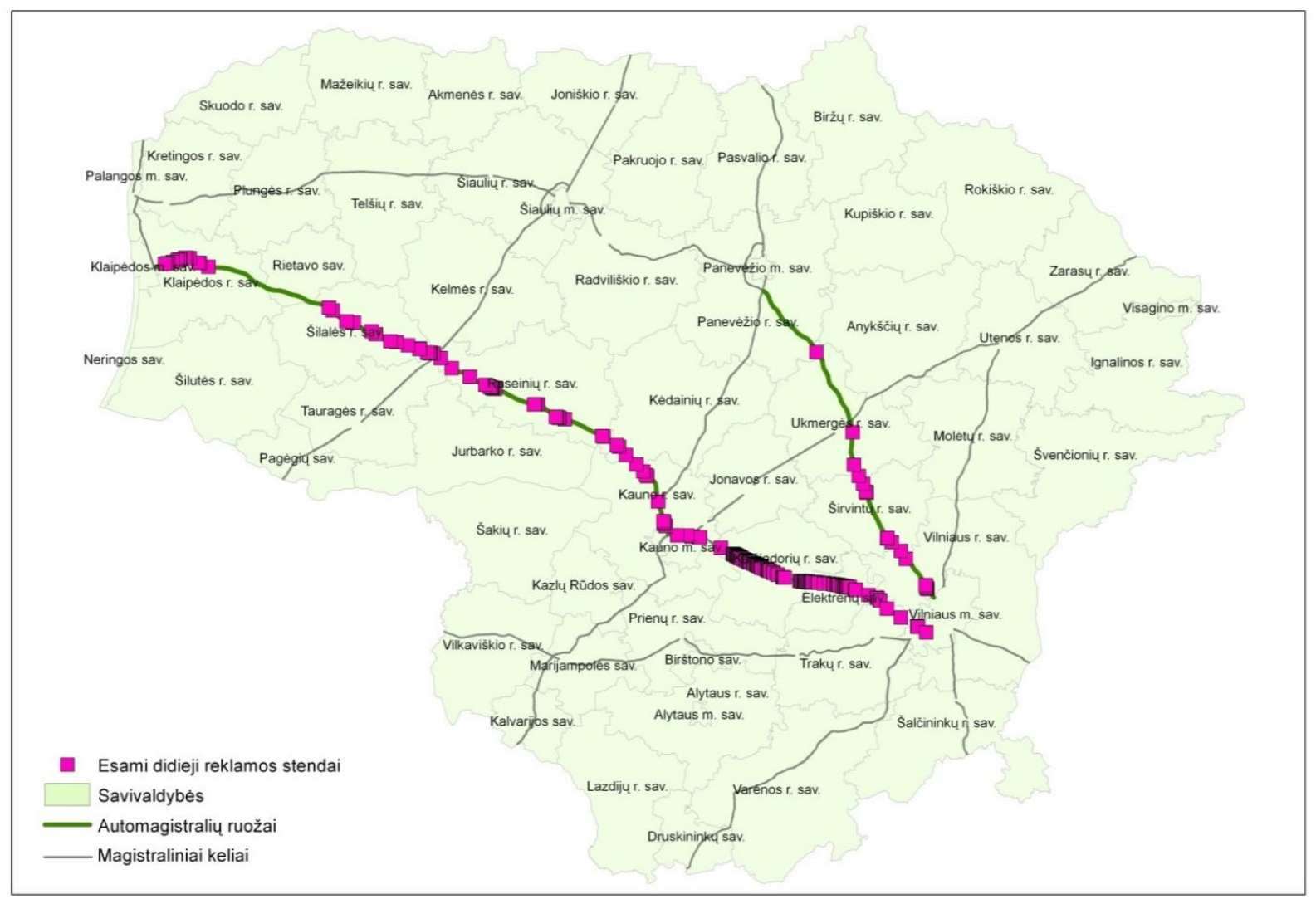

Fig. 1. Locations of FSB close to the main highways of Lithuania: Al Vilnius-Kaunas-Klaipeida and A2 Vilnius-Panevežys

Sizes of the FSBs differ greatly (ranging from $3 \times 6 \mathrm{~m}, 5 \times 15 \mathrm{~m}, 5 \times 15 \mathrm{~m}, 7 \times 15 \mathrm{~m}, 10 \times 15 \mathrm{~m}$ to $12 \times 40$ $\mathrm{m}, 20 \times 12.5 \mathrm{~m}$ etc). There are 11 very large, "giant" FSBs whose area reaches even several acres (e.g. 500 sq.m). The biggest dimension of such FSB is up to $\sim 40-50 \mathrm{~m}$.

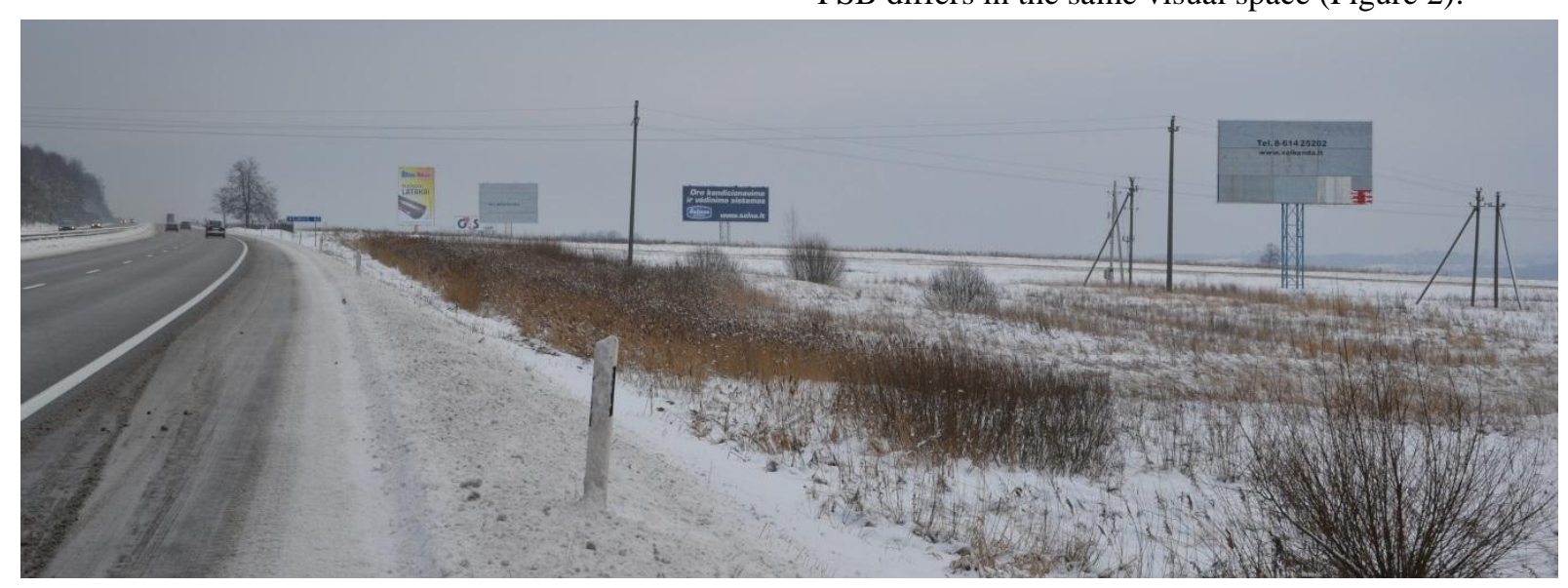

Rectangular FSBs dominate near the roads whose length is bigger than their height. FSBs, the height of which is bigger than the length, are noticed less frequently. They usually cut a horizon line and generate higher visual pollution than the others. Visual pollution is more intensive when the shape of FSB differs in the same visual space (Figure 2).

Fig. 2. FSBs of different sizes and shapes close to road Al between Vilnius and Kaunas 
In the analysed roads FSBs are located further than $70 \mathrm{~m}$ from the road lane as it is regulated by the Road Act of the Republic of Lithuania (LR Keliu... 2002). Due to the regulated distance, FSBs are mainly arranged in one line.

The biggest number of FSBs is between Žiežmariai and Rumšiškès and in the sector VievisElektrènai-Bačkonys. The most frequent and average distance between FSBs is equal to $\sim 200-350 \mathrm{~m}$; the smallest distance is $\sim 60-65 \mathrm{~m}$ (only one such case is found).

While assessing the FSBs visual impact on the landscape we followed a notion that positive influence of outdoor advertising on the landscape is impossible, because there is no such case when outdoor advertising objects can in any way improve it. The most negative visual impact of FSBs is on the natural landscape where forests, communities of shrubs and wild herbaceous plants and wetlands prevail. In this type of landscape they generate the highest visual contrast. An insignificant or neutral negative impact is impossible on this landscape type. According to the degree of a human impact on the environment the rural landscape is the best example of an anthropogenic landscape type. It is the rearranged but basically unchanged landscape in which human activity mostly harmoniously integrates into the natural environment. The rural landscape represents regional identity and life culture created over time. FSBs are incoherent in this type of the landscape, and any neutral impact is impossible. A negative impact of FSBs on the urban and suburban landscape is less striking, because these types of landscape are rich in other rapidly changing formations of human activity. However, there can be distinguished significant negative visual aspects of FSBs, namely, too high concentration, extremely different and/or aesthetically poor FSB design, inadequate size, too many FSBs of different types in one visual space, chaotic layout, unsuitable location etc. Therefore, the largest Lithuanian cities (Vilnius, Kaunas, Klaipeda) seek to control the construction of FSBs within the administrative boundaries by special plans (Vilniaus miesto... 2003, Kauno miesto... 2006, Klaipèdos miesto... 2005), in which the FSB construction areas are designated, FSB type, size and other characteristics are established.

\subsection{Worldwide experience of regulation of free standing billboards construction considering their visual impact on the landscape}

In order to ascertain the main principles of FSB construction regulation, the experience of Denmark, Finland, Scotland, Australia and Republic of South Africa (RSA) was analysed. Each country actualises FSB construction problems in its own way depending on the existing situation, on a general approach to the outdoor advertising techniques and tools and on understanding of the landscape value. We also analysed the experience of the UK and the USA in the field of visual impact assessment. The UK and the
USA are the first countries which have been concerned about evaluation of landscape visual resources and establishment of their protection and management objectives, i.e. the regulation of landscape visual quality by legal and planning tools.

\section{Regulation of FSB construction}

Regulation of FSB construction is very strict in Denmark, Finland, and Scotland. Particular attention is paid to both traffic safety and landscape in these countries. FSBs are allowed to be constructed only in urban areas. Natural and rural landscape of these countries is explicitly valued as the national asset.

Altogether, the Western European experience dealing with FSB construction issues does not reflect our country's situation. In Western European countries outdoor advertising is usually installed in urban areas as an adjusted measure. FSB construction, if not prohibited, is strictly limited and regulated, and the FSB size does not reach the "giant" FSB scale. Therefore, in order to solve specific problems the experience of other countries (Australia and RSA), where FSB category exists, is relevant.

The regulations of outdoor advertisement installation are very strict in Denmark. The country puts special emphasis on traffic safety and the landscape. FSBs are prohibited everywhere except urban areas where their installation permissions are issued by the municipalities. The legal framework of outdoor advertising installation consists of: the Roads Act (possible advertising installation conditions and exceptions are discussed), the Nature Conservation Act (advertising installation in open spaces of rural landscape is prohibited), and the Traffic Act (allows the controlling authorities to remove incorrectly installed signs and stands) (Outdoor Advertising... 2011).

Finland gives priority to traffic safety and roads landscape aesthetics, and installation of outdoor advertising is strictly controlled. Advertising is permitted only in cities, according to the prepared plans in which advertising installation locations are designated, criteria of control and responsibility are defined. In other areas, such as rural, forested areas, advertising installation is prohibited. FSB construction is regulated by the Roads Act which obliges the Road Directorate to be responsible for outdoor advertising near roads, the Planning and Building Act which determines advertising regulation possibilities in urban plans and control levels, the Road Traffic Act which establishes the responsibility for the road signs construction, and the Traffic Control Act which establishes official road signs and prohibits their use in advertising (Outdoor Advertising... 2011).

In Scotland the Town and Country Planning Act sets the principles of outdoor advertising installation based on public safety and creation of attractive public spaces. As in England, in Scotland responsibility for the control of outdoor advertising is assigned to the local authorities. Installation of FSB in 
road lanes is prohibited. Installation of advertising beyond the lane boundaries is controlled by the local authorities, but in the zone at a distance of $73 \mathrm{~m}$ from the road they must align their solutions with the transport service. Great attention is paid to the quality of road elements and marking. FSBs in rural landscape are prohibited (Outdoor Advertising... 2011).

In Australia construction of FSB is regulated by the Roadside Advertising Guide (Roadside advertising... 2009). FSB environmental impact is assessed in three aspects i.e. traffic safety, development perspective and the environment. The guidelines describe the requirements for FSB control, namely, issuance of the approval and authorisation, complaint analysis procedures. Impact on the landscape is assessed in two main aspects i.e. on the existing roads landscape (its ecological, aesthetic quality) and on noise barrier projects (acoustic walls etc). FSB construction is prohibited in valuable landscape areas: parks, historical and recreational areas, valuable vegetation areas, scenic landscapes, natural landscapes and landscapes with open spaces.

Republic of South Africa issued the South African Manual for the Outdoor Advertising Control (SAMOAC) (South African Manual... 1998). Its main function is to classify, evaluate and control outdoor advertising. SAMOAC is consistent with the existing juridical basis and is used to solve specific advertising construction issues. Advertising stands, depending on size and type of installation, are divided into classes. FSBs are classified as Class 1, which in its turn is divided into sub-classes: a) super stands, b) custommade stands, c) large stands and d) small stands. Each class has different requirements, for example, super stands $(40-81 \mathrm{~m} 2)$ are built not closer than $5 \mathrm{~km}$ from each other; on the main roads at a minimum distance of $200 \mathrm{~m}$ from the intersection; on the other roads - not closer than $100 \mathrm{~m}$ from the intersection. Advertising installation is also controlled according to the type of the landscape: natural, rural, and urban. Advertising installation control consists of three levels: maximum control (natural, rural landscape, and some urban landscape zones, e.g. conservation, recreation, scenic areas, gateways etc), partial control (particular areas of the urban landscape: residential areas with highrise apartment blocks, educational institutions, suburban shopping centres and office parks etc), and minimum control (particular areas of the urban landscape: commercial districts, central shopping centres, industrial areas, entertainment complexes, prominent public transport nodes etc). The construction of FSBs is regulated according to the general traffic safety requirements as well.

\section{Experience of visual impact assessment}

The concept of environmental impact assessment (EIA) originated in America, partly because of its extra-rigid system of zoning. Planning control in some American states was much less comprehensive than in Europe and there was a great public concern about the harmful effect which individual development projects were having on the environment. The National Environmental Policy Act (NEPA) of 1969 became a model for similar legislation throughout the world (Environmental impact... 2008). This act also states that all Americans have the right to the aesthetically attractive environment. EIA is understood as an evaluation of an impact of every aspect of the planned object or activity on every aspect of the environment. The matrix of evaluation of aspects interaction is used for this purpose. There is the evaluated impact of project earthworks, waterworks, vegetation, paving, walling and building on the natural environment (physical and biological), on the social environment (circulation and recreation) and on the spatial environment (views, spaces, skylines) (Turner 2003, Visual Resource... 2012). Project correspondence with visual environment management objectives is evaluated and a possible negative impact is mitigated according to the contrast rating method developed by the Bureau of the Land Management. A visual contrast rating process involves comparing the project features with the major features in the existing landscape using the basic design elements of form, line, colour and texture. The degree to which management activity affects the visual quality of the landscape depends on the visual contrast created between the project and the existing landscape. This assessment process provides the means for determining visual impacts and for identifying the measures to mitigate these impacts. Project features which repeat the basic design elements found in the landscape are visually compatible with the contextual environment. Project features which make contrast with the contextual environment according to the basic design elements are assessed as positively or negatively influencing the landscape visual quality taking into account visual environment management objectives. The basic design elements are the main measures to achieve harmony of the project and the environment reducing a negative visual impact.

In 1995 the Landscape Institute (UK) published the Guidelines for the landscape and visual impact assessment (VIA) for the first time. Visual impact is defined as a change in the appearance of the landscape as a result of development which can be positive (improvement) or negative (detraction) (Morris and Therivel 2001, Guidelines for Landscape... 2002).

Main stages of visual impact assessment are: screening (determines the need of EIA) and scoping (identifies the scope and content of EIA); project description and description, classification and evaluation of visual resources of surrounding landscape; systematic identification of potential impacts, prediction of their magnitude and assessment of their significance; establishment of the measures to avoid, reduce or offset negative effects of the development proposals.

During the process of VIA the type and magnitude of visual impact of the proposed development is determined according to its visual compatibility with the surroundings (e.g. massing, 
height, shape, proportion and rhythms of building elements, colour and material used) and the role of it in the visual environment: formation of visual obstruction (e.g. blocking of views towards existing landscape features; or existing/planned view corridors towards landmarks and notable features) or improvement of visual quality (e.g. clearance of visual obstruction and blight, appealing design features that enhance attractiveness of the landscape) etc.

A very important stage of VIA is evaluation of visual impact significance. Impact significance is a combination of impact magnitude and sensitivity of the receiving landscape and viewers. Sensitivity of the landscape potentially affected by a proposed development is based on the degree to which the landscape is able to accommodate the change without unacceptable effects on its character. The most sensitive is the protected landscape. The criteria of landscape sensitivity to the proposed development are the following: rarity and representativeness, social significance, visual quality, localisation of visual pollution, distinctiveness and identity, conservation interests, professional and public opinion. For example, sensitive landscape and its large change result in a high significance of impact, the landscape of low sensitivity and its large change result in a moderate significance of impact.

To sum up the experience of foreign countries in the field of VIA, it can be said that these countries, unlike Lithuania, have validated the concepts of landscape visual quality and planned activity or visual impact assessment of the object, the methodological recommendations of visual impact assessment based as much as possible on the principles of objectivity and systematics, which are used in practical activities of planning and design.

\subsection{Methodological guidelines for regulation of free standing billboards construction taking into account their visual impact}

Significant improvement of the landscape visual quality can be achieved by removing FSBs from rural and natural landscapes and applying high standards for FSBs layout, aesthetic quality and technical state in the urban and suburban landscapes. Special plans should be prepared to designate FSB construction zones there. In the first stage special plans for the FSB construction procedure of the visual impact assessment should be drawn to identify the most appropriate locations and character of the FSBs in a particular construction zone. Considering the existing situation and foreign experience in regulating outdoor advertisement development and VIA we propose the following stages of FSB visual impact assessment:

- $\quad$ Analysis of landscape spatial structure

Limits of visual spaces (VSs) and road sections from which VSs are perceived are identified and marked. The area is assessed from the spatial (observing locations as road sections are identified) and quantitative (spaces of visual use are established) points of view. This determines the size of an FSB visual impact zone considering the road location (Figure 3).

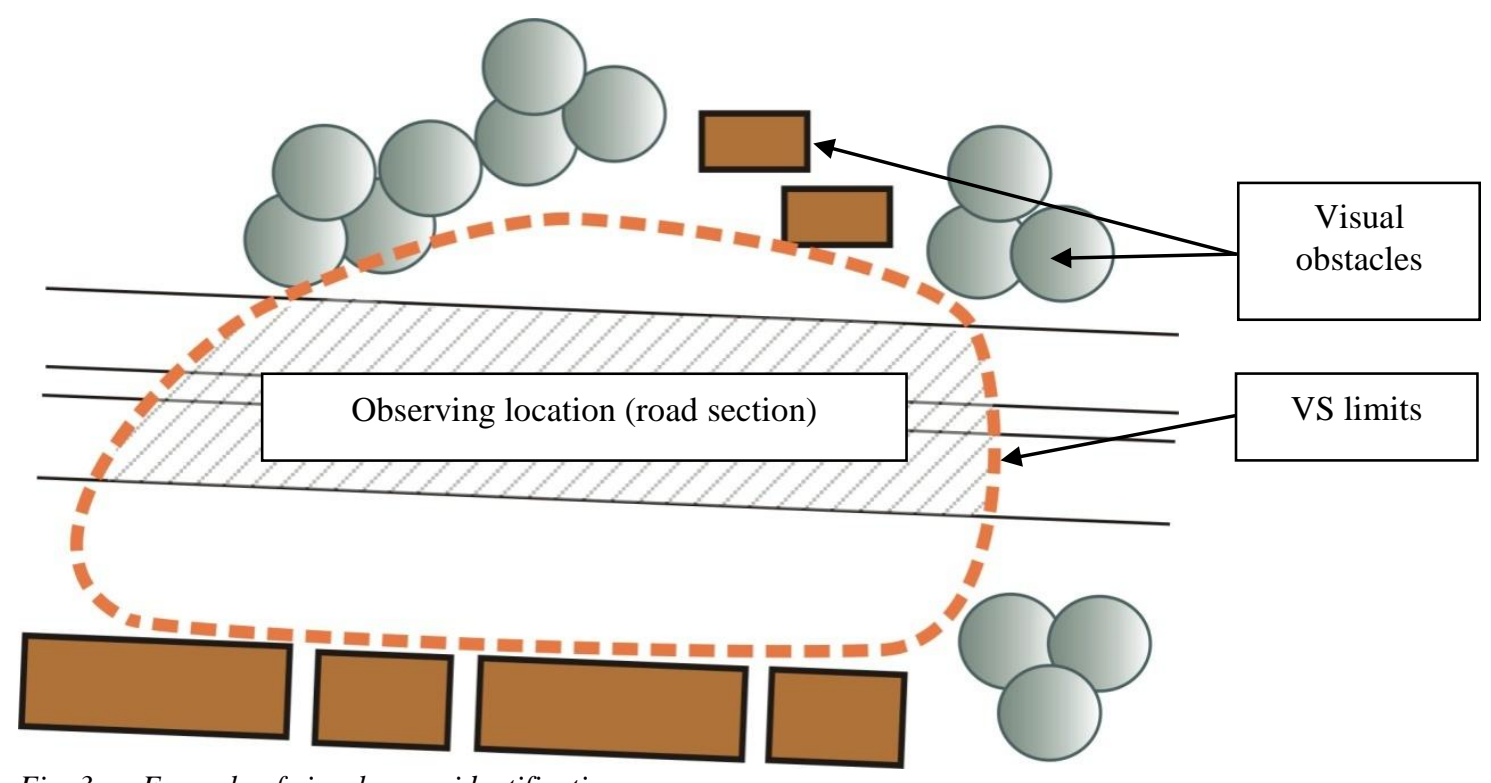

Fig. 3. Example of visual space identification

Visual spaces are the spaces which are directly perceived as integral formations from any observing point located inside of them (Kamičaityte Virbašienè 2003, 2011, Purvinas 1975). Their size according to the viewing radius can vary from $5-10$ meters to several kilometers considering the structure of Lithuanian landscape. Such space is an elementary cell of the landscape spatial structure perceived visually and such unit should be used for analysing and evaluating the landscape to regulate the FSB construction.

Main quantitative and qualitative indicators of a spatial structure of the visually perceived landscape which have to be evaluated while regulating FSB 
construction are (Kamičaityte - Virbašienè 2003, 2011, Purvinas 1975, 1983) the following: size of VS, configuration, vertical and horizontal closure, visual connections between different VSs, hierarchy of VSs (number of VSs ranks), integrity of VSs, naturalness, variety and degree of dominance of the objects forming VSs. A viewing radius is the main indicator of VS size. Physical possibilities of viewing determine the viewing radius and at the same time the VS types according to their size. VS configuration determines the possibilities of perception of VS as an integral formation, i.e. the simpler the VS plan form the stronger possibilities to perceive it as a whole from any point in it, and the stronger possibilities for FSB to dominate in it. Horizontal closure is expressed as percentage of visual obstacles limiting VS in the perimeter of VS. Vertical closure is expressed as a viewing angle of the visual obstacles limiting VS. Hierarchy of VSs is very important while analysing the landscape structure of a larger area when there are several VSs. The place of VS in the hierarchy of VSs determines its character and visibility of FSB. Visual connections between different VSs correlate with horizontal closure. When horizontal closure is partial, the visual connections with adjacent visual spaces occur and FSB can be visible in more than one VS. VS integrity determines whether visual obstacles are inside of VS which divide it into the other lower-level VS. Naturalness of VS is determined by character, quantity and dominance of visual obstacles. Visual obstacles can be natural, anthropogenic and anthropogenised (e.g. man-made terrain, planted greenery etc). The higher the naturalness of VS the more intensive visual contrast of FSB with the contextual environment occurs. Variety of VSs is conditioned by the quantity and layout of natural, anthropogenic, and anthropogenised landscape components (visual obstacles). The greater the variety of VSs the less intensive visual contrast of FSB with the contextual environment occurs. A degree of dominance of the objects forming VS determines impressiveness, compositional value and overall visual quality of VS. Dominant objects can be hills, unique public buildings or, on the contrary, abandoned industrial sites which are perceived as visual pollution etc. FSB cannot be constructed in the area of visual influence of valuable landscape components but can mask the objects of visual pollution.

\section{- $\quad$ Analysis of FSB layout possibilities}

Function, cultural and historical significance, visual impressiveness of the spaces (using the method of overall impression (Kamičaitytè - Virbašienè 2003) are determined in this stage. Spaces of the suburban landscape which are protected from construction of FSBs are identified, for example, the spaces representing historic landscape types, panoramic views of Lithuanian cities and towns, spaces of the hilly laky forested natural landscape, and other scenic views of natural, rural or urban landscape visual type, which can be distinguished in a suburban area.

The construction site for FSBs is designated referring to the following criteria:
K1 -visual quality of the landscape (it is evaluated using the method of overall impression, or the material of previous research on the landscape aesthetic potential is used);

K2 - function of the area (FSBs can be constructed in industrial areas, zones of the technical or social infrastructure, mixed residential areas etc which are designated according to the type of land use (Miestų, miestelių... 2009));

$\mathbf{K 3}$ - distance to the objects of natural and cultural heritage (FSBs cannot be constructed in the visual protection zones of natural and cultural heritage objects);

K4 - distance to the road transport service and recreation infrastructure (FSBs can be constructed as part of transport service and recreation infrastructure complex);

K5 - distance to residential areas (FSB construction in residential areas is unacceptable).

With regard to the observer the road divides the landscape transversely and longitudinally. However, the transverse division will be perceived only as a change of the functional and visual landscape type. Longitudinal division can be understood in two ways i.e. when we have the same landscape type to the left and right from the road (e.g. the same cultivated fields), or we have one landscape type on the left and another landscape type on the right side of the road (e.g. cultivated fields and a village) (Kamičaitytė Virbašienè and Žebrauskas 2007).

Considering the structure and quality of visual spaces of the road environment, FSBs can be constructed in the following ways (Table 1):

I. If the road divides the space of high visual quality (visual quality of the space meets the criteria of vitality, complexity, compositional harmony, expressivity, uniqueness, functionality and meaningfulness), the construction of FSBs is forbidden.

II. If the road divides the space of moderate visual quality (visual quality of the space partially meets the criteria), it is possible to construct a single FSB following these installation and layout requirements:

a) modular integrity of FSB size and shape;

b) modular integrity of the interval between FSBs;

c) constructional material uniformity and representativity of FSB.

III. If the road divides the space of low visual quality (visual quality of the space does not meet the criteria), there is a zone of FSB construction in which it is possible to construct a single FSB following the above mentioned requirements of installation and layout or groups of them applying these additional requirements:

a) layout of FSB groups only on the left or on the right side of the road;

b) layout of FSB groups on both the left and right sides of the road applying a chessboard principle and increasing informational diversity of the landscape; 
c) layout of FSB groups on both the left and right sides of the road leaving undeveloped modular transverse spaces between them.

IV. If the road divides the space of different visual quality, the construction of FSB is possible using the above mentioned requirements of installation and layout in accordance with the opportunities matrix of the layout of FSB in VS of the road environment (Table 1).

Table 1. Matrix of layout opportunities of FSB in VS in the road environment

\begin{tabular}{||l|l|l|c||}
\hline $\begin{array}{l}\text { Quality of VS on the left side of the } \\
\text { road }\end{array}$ & High visual quality & $\begin{array}{l}\text { Moderate visual } \\
\text { quality }\end{array}$ & Low visual quality \\
\hline $\begin{array}{l}\text { Quality of VS on the right side of } \\
\text { the road }\end{array}$ & & & \\
\hline High visual quality & - & - & $-/+$ \\
\hline Moderate visual quality & - & + & + \\
\hline Low visual quality & $-/+$ & + & + \\
\hline
\end{tabular}

- construction of FSB is forbidden;

+ construction of FSB is possible;

$-/+$ construction of FSB is possible in the part of the space of a lower visual quality.

- Establishment of the possible visual contrast level of FSB

Contextuality should be the main principle of FSB integration into the landscape. Level and character of contextuality are established according to the visual impact assessment of the designed structure. After the analysis of its visibility visual contrast of the structure is evaluated according to the visual relation of physical and visual features of the structure and the environment.
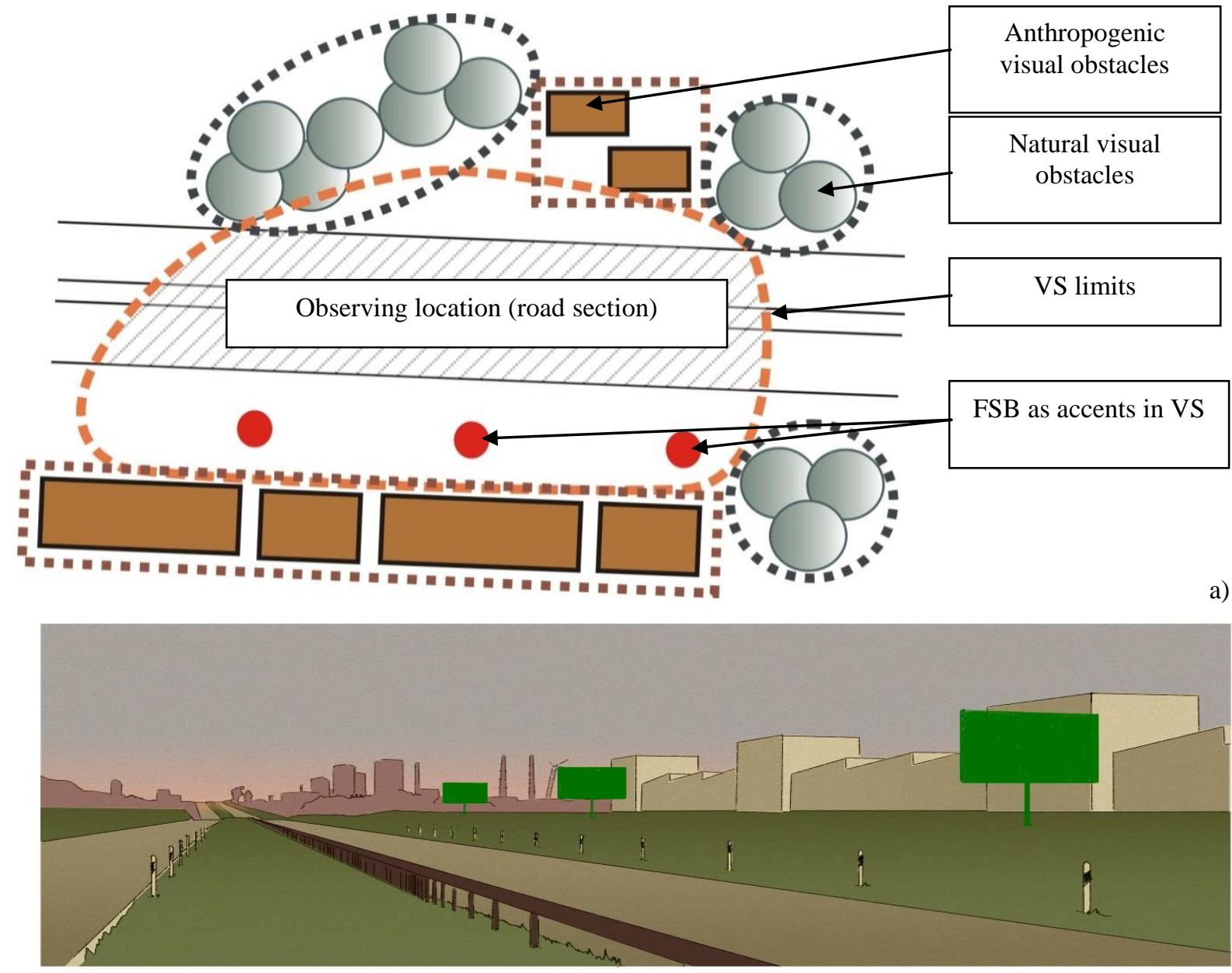

Fig. 4. Example of visual space analysis and FSB allocation in plan (a) and in space (b)

The Identity Index Context (SID) theory (Turner 2003) states that the type and levels of contextuality can be quantitatively determined by the identity index. This index can be used to define the extent to 
which FSB will be identical with, similar to, or different from its context. Visual contrast of FSB can reach the second or third levels, whereas advertising seeks to catch attention by its nature.

During this stage there are analysed quantity, character and layout of visual obstacles, visual significance of natural and anthropogenic components (structural comparative analysis). The most visually active objects are called dominants. Accents are the elements which attract our attention and can be distinguished from the contextual environment. The majority of homogenous elements form the background. This leads to a potential FSB contrast level - dominant or accent (Figure 4)

The level of FSBs visual contrast depends on the conception of the landscape formation. FSBs can be perceived as visual accents in an agrarian urbanized landscape, in a forested or agrarian slightly urbanized landscape. In an urban landscape (e.g. in industrial, commercial, mixed residential and other areas) they can be accents or dominants (Figures 5, 6).

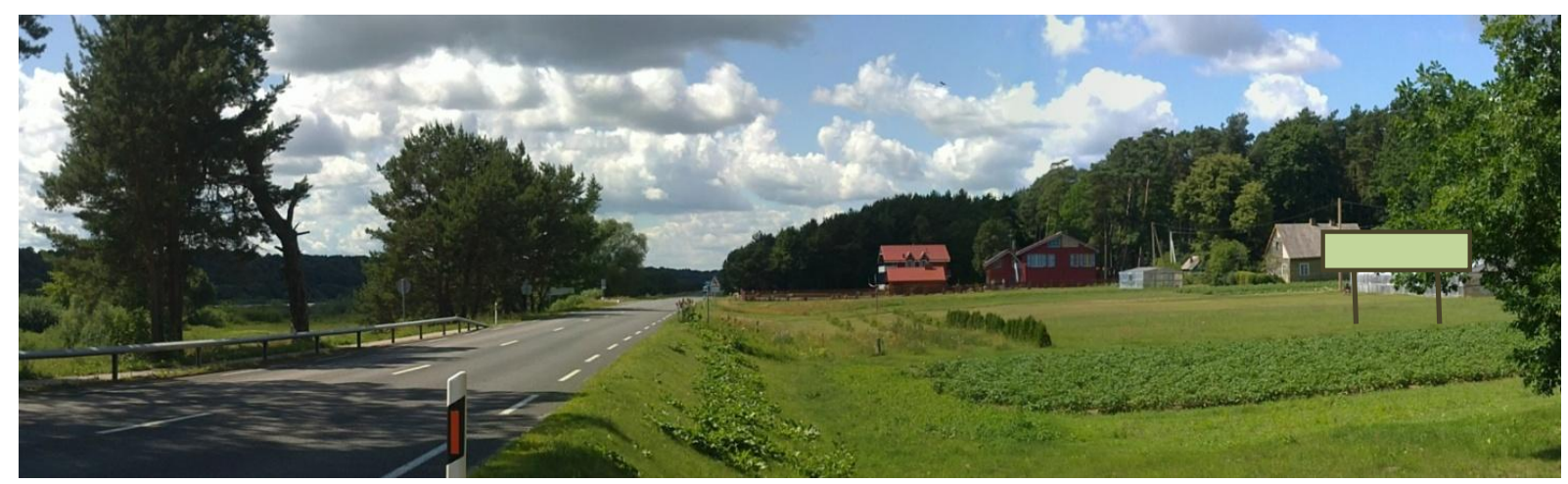

a)

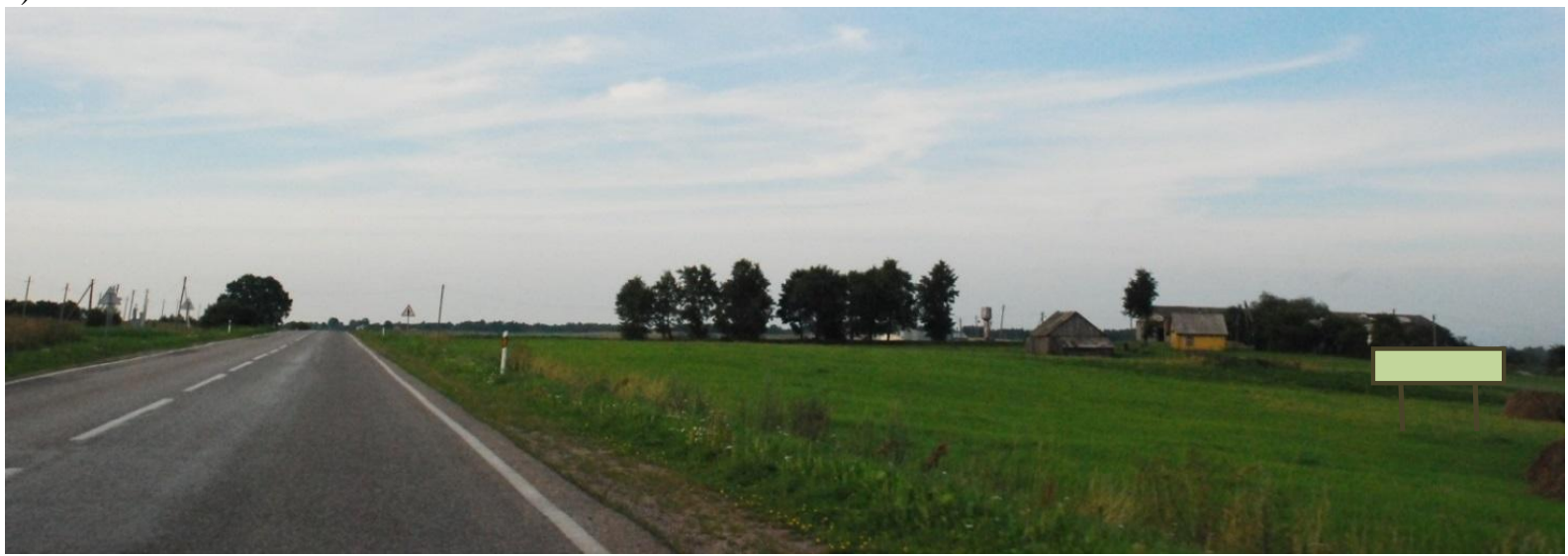

b)

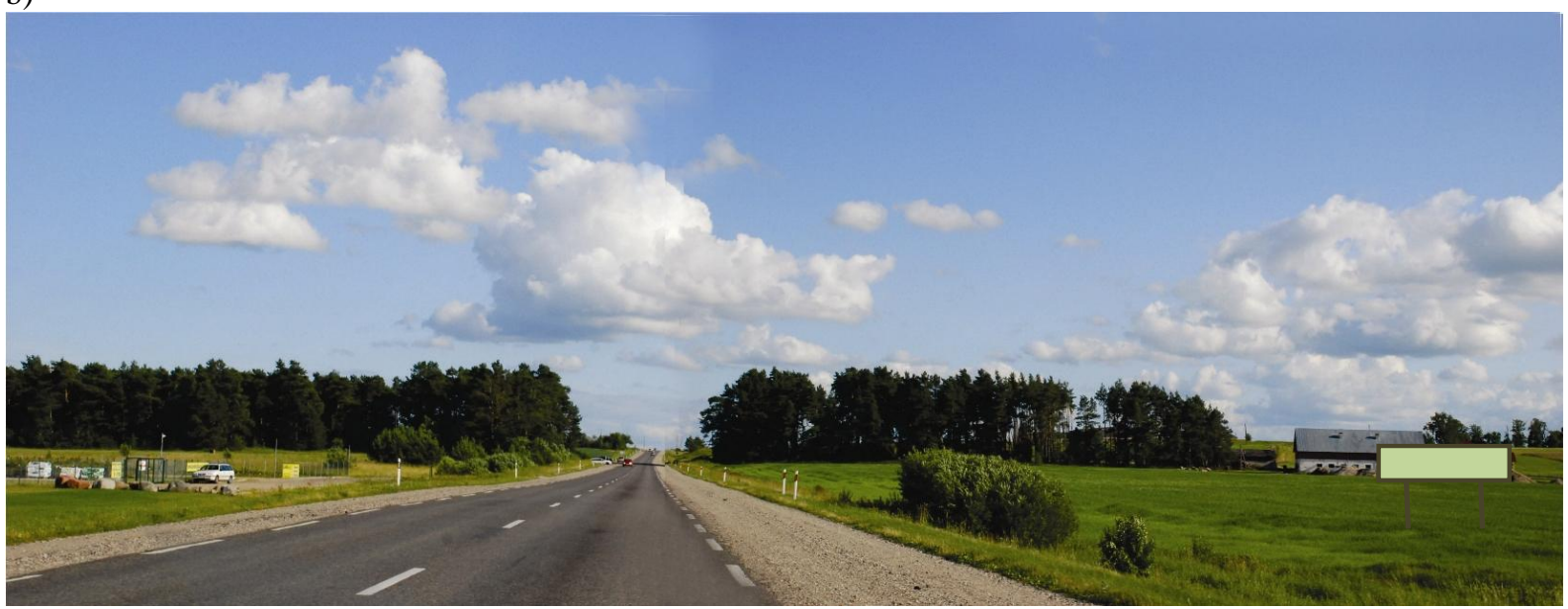

c)

Fig. 5. Examples of FSB layout and visual contrast level in forested (a) and agrarian slightly urbanized (b, $c$ ) landscape of a suburban zone: FSBs do not cross a horizon line and are perceived as accents in the visual space

- $\quad$ Establishment of FSB location in VS and visual contrast character

Visual contrast character of FSB can be very diverse, for example, the identity indices of the FSBs and the environment can be the following: shape $90 \%$, materials $-80 \%$, colours $-20 \%$ etc. These values mean that the shape and materials are identical with the contextual environment, while colours differ 
from it. The meanings of these indicators are conditioned by the urbanisation level and the functional purpose of the area, its cultural and historical significance and spatial structure and composition (character and layout of visual dominants, accents and background elements and their physical and visual features).

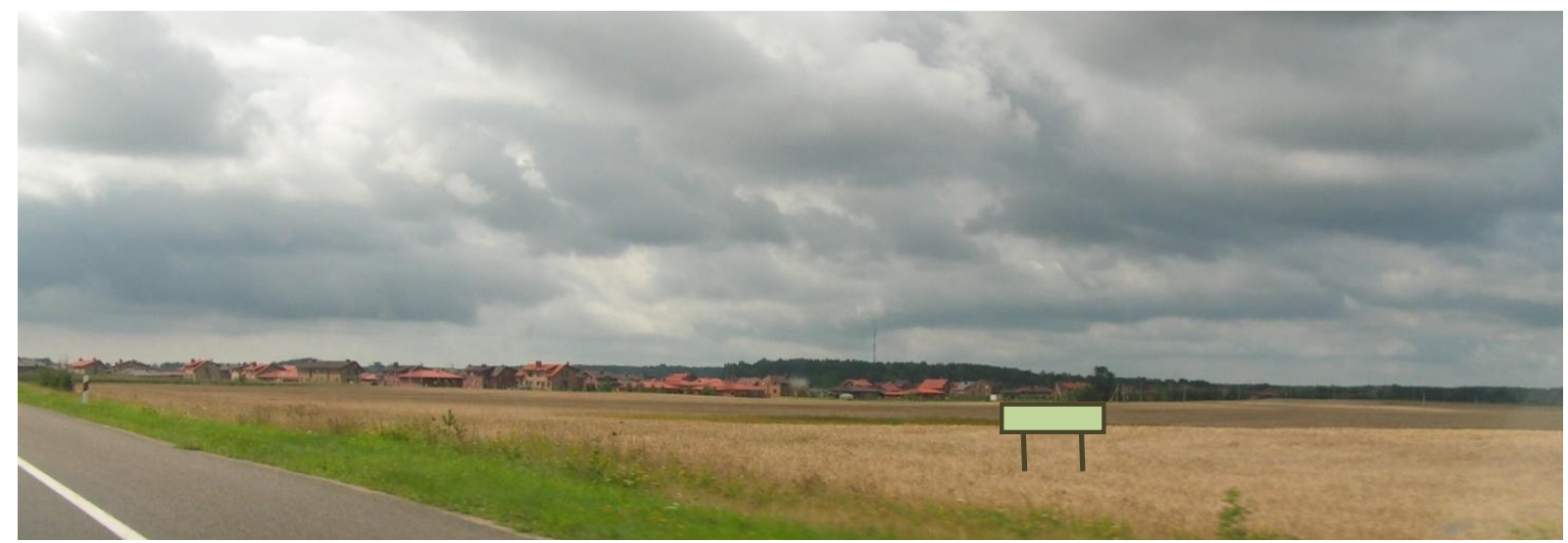

a)

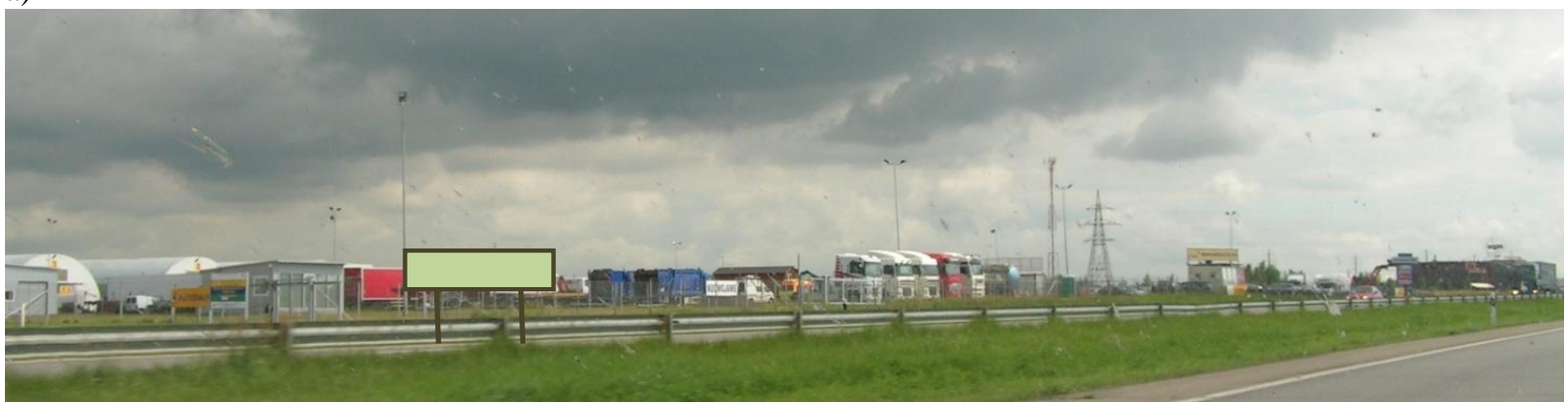
b)

Fig. 6. Examples of FSB layout and visual contrast level in agrarian urbanized (a) and urban (b) landscape of a suburban zone: FSB does not cross horizon line and is perceived as an accent in the visual space of the agrarian urbanized landscape (a); FSB crosses a horizon line and dominates in the visual space of the urban landscape (b)

During this stage there are analysed the aesthetic semantic values, compositional harmony, physical and visual features of VS components. The importance of landscape components to the formal composition is analysed (positive or negative dominant, accent or background element). The semantic meaning of landscape components (of buildings, their complexes, or natural objects) is also established (amount of meaningful information and its content are analysed which determine if the analysed object is a symbol, a sign forming the identity, or landmark of the site). Physical and visual features of VS components are analysed as well: predominant scale, materials, constructions, shapes and colours. This determines FSB location in the VS, its contrast character considering its size, materials, constructions, shape and colour (Figures 5, 6). For example, in Figure 5c FSB visually masks the abandoned agricultural production building, in Figures $5 \mathrm{a}, \mathrm{b}$ and $\mathrm{c}$, and $6 \mathrm{a}$ FSBs are perceived as visual accents according to the scale, shape and colour, in Figure 6b FSB dominates in VS according to the scale and colour.
The proposed contrast levels of FSB physical and visual features and those of suburban landscape types according to the SID theory (Turner 2003) are shown in Table 2. The value of the identity index equal to $10-30 \%$ means that FSB is different from the contextual environment according to the analysed aspect, $31-60 \%$ means that FSB is similar to the contextual environment according to the analysed aspect, and $61-90 \%$ means that FSB is identical with the contextual environment according to the analysed aspect.

The proposed contrast levels of FSB physical and visual features and those of suburban landscape types also depend on distance (viewing radius), vehicle speed, time of day, weather conditions, lighting, advertising area font type, background colour, texture and other subjective and objective indicators. Evaluation of the above mentioned aspects and preparation of more elaborated recommendations for FSB construction are the tasks for the future research for which we are already preparing some proposals concerning FSB shape, size and layout possibilities. 
Table 2. Contrast levels of FSB and landscape visual types of a suburban zone

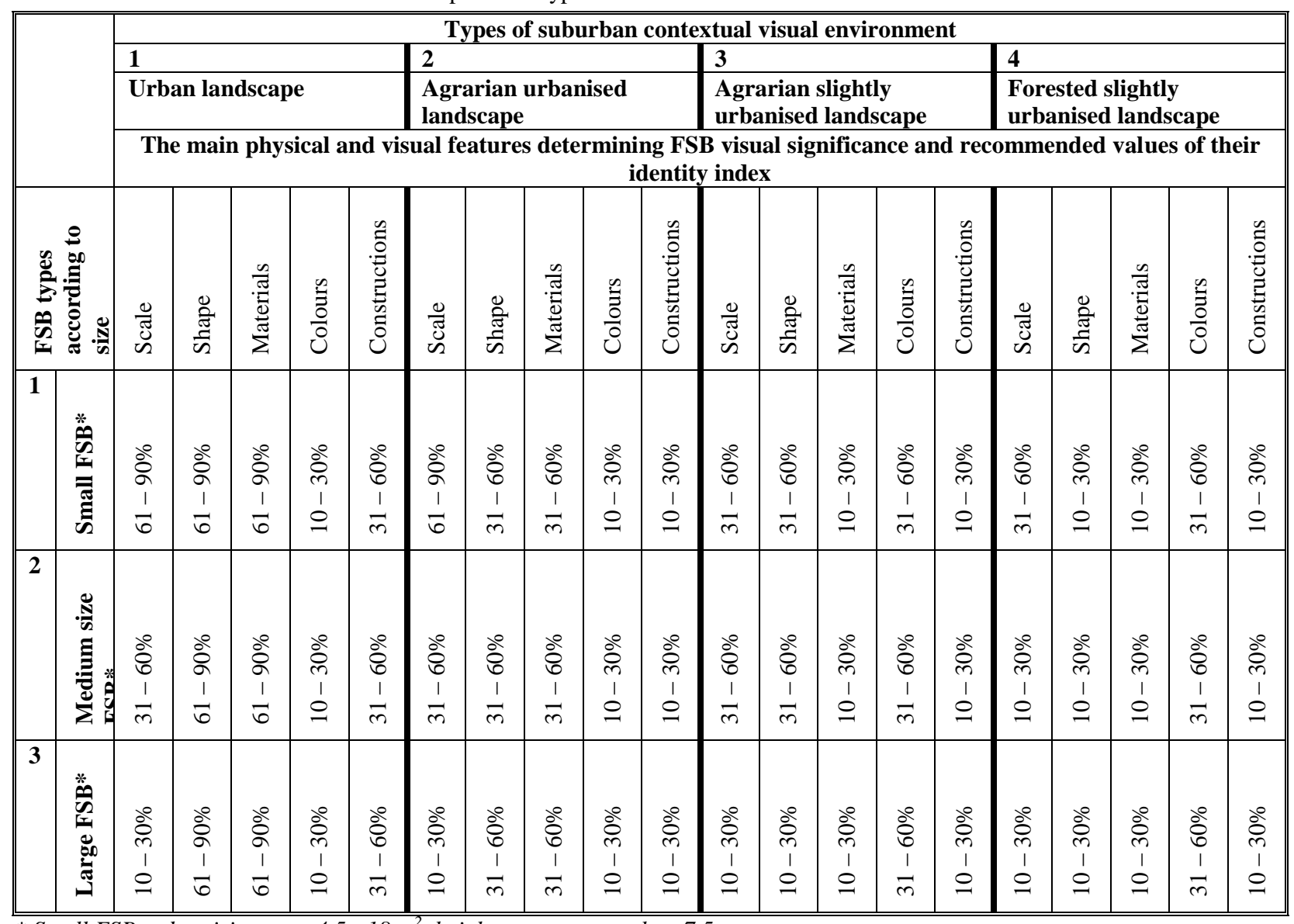

* Small FSB: advertising area $4.5-18 \mathrm{~m}^{2}$, height - not greater than $7.5 \mathrm{~m}$;

Medium size FSB: advertising area $18-36 \mathrm{~m}^{2}$, height-not greater than $7.5 \mathrm{~m}$;

Large FSB: advertising area $36-108 \mathrm{~m}^{2}$, height-not greater than $12 \mathrm{~m}$.

According to the size of an advertising area FSBs are classified into small, medium and large (Table 2). The plane of an FSB rectangular advertising area is to be oriented horizontally.

The height and length ratio should be 1:2, 1:2.5, $1: 3$, or 1:4. The FSB advertising area cannot be lower than 3 meters from the ground. FSBs should not cross the horizon line observing them at a distance equal to the viewing radius of particular VS. FSBs must be designed and installed at equal distances between the devices, parallel to the edge of the carriageway, further than the limit of the road protection zone. They can be placed in several rows, forming a group behind the limit of the road protection zone as well, but not further than $250 \mathrm{~m}$ from the limit of the road protection zone. The recommended distances between FSBs are the following: between small FSBs - not shorter than $200 \mathrm{~m}$, between medium size FSBs - not shorter than $250 \mathrm{~m}$ and between large FSBs - not shorter than $350 \mathrm{~m}$.

\section{Conclusions}

Free standing billboards (FSBs) have a significant negative visual impact on the landscape. In Lithuania the construction of FSBs considering their impact is too little regulated by juridical and spatial planning means. Lithuanian and foreign theoretical methodological basis of visual impact assessment (VIA) and legal measures of FSB construction regulation which are taken in the analysed foreign countries allowed us to draw the following conclusions:

- FSBs have to be removed from the spaces of a natural and rural landscape. They can be constructed only in suburban and urban landscapes according to the special plans, applying methodological guidelines of FSB VIA and, in this way regulating the layout, physical and visual indicators of FSBs.

- The main purpose of the special plans of FSB construction is division of the planned area into the zones according to the possible FSB types and their construction techniques. These plans should designate the zones for construction of FSBs, determine the distances between them, their proportions, heights, shapes, constructions, materials, etc and the sizes of advertising areas.

- VIA should be a constituent part of the preparation process of special plans. The proposed stages of VIA of FSB are the following: analysis of the landscape spatial structure designating visual spaces (VSs) perceived from separate road sections; analysis of FSB layout possibilities designating VSs protected from FSB construction and VSs as FSB construction areas; establishment of the 
possible visual contrast level of FSBs, and establishment of FSB location in VSs and visual contrast character according to the SID theory and the results of evaluation of VS according to the criteria of vitality, complexity, compositional harmony, expressivity, uniqueness, functionality and meaningfulness.

- The proposed methods of FSB layout in VSs elaborates FSBs layout possibilities according to the quality of vss: if the road divides the space of high visual quality, the construction of FSBs is forbidden; if the road divides the space of moderate visual quality, it is possible to construct a single FSB; if the road divides the space of low visual quality, it is regarded as a zone of FSBs construction.

\section{References}

Dèl poveikio aplinkai vertinimo programos ir ataskaitos rengimo nuostatu patvirtinimo: Lietuvos Respublikos aplinkos ministro įsakymas, $2005 \mathrm{~m}$. gruodžio 23 d., Nr. D1-636. URL:

http://www3.lrs.lt/pls/inter3/dokpaieska.showdoc_1?p_i $\mathrm{d}=269471 \&$ p_tr2=2. [Online: accessed 24th September 2013].

Environmental impact design. 2008. URL: http://www.gardenvisit.com/landscape_architecture/landsca pe_plans_planning/eid_environmental_impact_design.

[Online: accessed 8th September 2013].

Guidelines for Landscape and Visual Impact Assessment, 2002. The Landscape Institute with the Institute of Environmental Management and Assessment. Spon Press, London and New York.

Kamičaitytė - Virbašienė, J. Kraštovaizdžio vizualinès kokybės reguliavimas kraštotvarkoje (Lietuvos pavyzdžiu): disertacija, 2003. P.193. Technologija, Kaunas.

Kamičaitytė - Virbašienè, J. Metodinès rekomendacijos kraštovaizdžio formavimo individualiam darbui atlikti: mokomoji knyga, 2011. P. 53. Vilniaus pedagoginio universiteto leidykla, Kaunas [i.e. Vilnius].

Kamičaitytè-Virbašienè, J., Žebrauskas, T. 2007. Išorinès vaizdinès reklamos vizualinio poveikio reglamentavimo siūlymai intensyvaus eismo ruožuose, p. 152-158. Pažangioji statyba: konferencijos pranešimu medžiaga, Kauno technologijos universitetas, Kaunas.

Kauno miesto išorinès vaizdinès reklamos specialusis planas. 2006. URL:

http://www.kaunas.lt/index.php?3385250692. [Online: accessed 24th September 2013].

Klaipèdos miesto vizualinès informacijos bei išorinès reklamos specialusis planas. 2005. URL: http://www.klaipeda.lt/go.php/lit/Specialieji-planai-irschemos/1753. [Online: accessed 24th September 2013].

Lietuvos Respublikos Kelių istatymo pakeitimo istatymas, $2002 \mathrm{~m}$. spalio 3 d., Nr. IX-1113. URL: http://www3.lrs.lt/pls/inter3/dokpaieska.showdoc_1?p_id=1 88756\&p_tr2=2. [Online: accessed 24th September 2013].

Lietuvos Respublikos Reklamos istatymo pakeitimo istatymas, $2013 \mathrm{~m}$. gegužès 16 d., Nr. XII-315. URL: http://www3.lrs.lt/pls/inter3/dokpaieska.showdoc_1?p_id=4 49267\&p_tr2=2. [Online: accessed 24th September 2013].

Miestu, miestelių ir kaimų (gyvenamujų vietovių) planavimo normos. 2009.2 URL: http://www.am.lt/VI/files/0.456798001240561714.pdf.

[Online: accessed 24th September 2013].
Morris, P., Therivel. R. Methods of Environmental Impact Assessment. 2001. P. 492. Spon Press, London.

Outdoor Advertising Control Practices in Australia, Europe and Japan, 2011. FHWA International Technology Scanning Program, United States.

Purvinas, M. Kraštovaizdžio architektūrinès analizès taikymas projektavime. Lietuvos TSR architektūros klausimai, 1983, t. 8, sąs. 1, p. 46-52.

Purvinas, M. Kraštovaizdžio erdvinès struktūros pirminiai vienetai ir jų galimos charakteristikos. LTSR Aukštuju mokyklų mokslo darbai. Statyba ir architektūra, XIV. Architektūra ir miestų statyba, 1975, t. 4, p. 5-21.

Roadside Advertising Guide, 2009. Queensland Government, Department of Main Roads, Australia.

South African Manual for Autdoor Advertising Control, 1998. Department of Environmental Affairs and Tourism Directorate, South Africa.

Studija dèl išorinès vaizdinès reklamos îrengimo magistralinių kelių apsaugos zonoje, 2005. Valstybinès reikšmès kelių priežiūros ir remonto norminių aktų ir norminių dokumentų rengimas, III TOMAS. VI Transporto ir kelių tyrimo institutas, Kaunas.

Turner, T. Landscape planning and environmental impact design, 2003. P. 425. UCL Press, London.

Vilniaus miesto išorinès vaizdinès reklamos specialusis planas. 2003. URL:

http://www.vilnius.lt/index.php?2728112018. [Online: accessed 24th September 2013].

Visual Resource Management System. 2012. URL:

http://www.blm.gov/wo/st/en/prog/Recreation/recreation_na tional/RMS/2.html. [Online: accessed 8th September 2013].

Prof. Dr. Jūratė Kamičaitytė-Virbašienė Department of Architecture and Land Management, Kaunas University of Technology.

Main research areas: landscape visual quality analysis, evaluation and regulation, methods of visual impact assessment, social preferences evaluating landscape visual quality and use of the analysis results in territory planning, sustainable development in architecture, construction, town planning and landscape.

Address: Studentu st. 48,

$$
\begin{aligned}
& \text { LT-51367 Kaunas, } \\
& \text { Lithuania }
\end{aligned}
$$

Tel.: $\quad+37037451546$

E-mail: jurate.kamicaityte@ktu.lt

\section{Ona Samuchovienè - Joint Stock Company}

"Infraplanas", Environmental Senior Specialist, Master of Geography.

Main research areas: environmental impact assessment, assessment of roads, railways, wind power plants impact on landscape and land use.

Address: K. Donelaičio st. 55-2,

$$
\text { LT-44245 Kaunas, }
$$

\section{Lithuania}

Tel.: $\quad+37037407548$

E-mail: o.samuchoviene@infraplanas.lt 


\title{
Didieji komercinès reklamos stendai Lietuvos kelių kraštovaizdyje: jų vizualinis poveikis ir reguliavimo galimybės
}

\author{
J. Kamičaitytè-Virbašiené $\dot{1}^{1}$, O. Samuchoviené $\dot{2}^{2}$ \\ ${ }^{1}$ Kauno technologijos universitetas, Statybos ir architektūros fakultetas, Lietuva \\ ${ }^{2} U A B$,,Infraplanas “, Lietuva
}

(gauta 2013 m. rugsèjo mèn.; atiduota spaudai 2013 m. gruodžio mèn.)

\begin{abstract}
Didieji komercinès reklamos stendai daro reikšmingą neigiamą vizualini poveikị kraštovaizdžiui. Išsivysčiusiose užsienio šalyse išorinès vaizdinès reklamos stendų statyba yra reglamentuojama ịvairiais teisiniais aktais, gairèmis, kontrolès vadovais. Lietuvoje komercinès reklamos stendų statyba, ỉvertinant jų vizualini poveikị kelių kraštovaizdžiui teisinemis ir teritorijų planavimo priemonèmis, praktiškai nèra reguliuojama. Atsižvelgiant i šią situacija, straipsnio tikslas - apžvelgti Lietuvos problemas, reglamentuojant didžiujų komercinès reklamos stendų statybą ir jų poveiki kraštovaizdžiui, ivvertinti užsienio šalių patirti, sprendžiant šias problemas, ir pateikti metodines didžiuju komercinès reklamos stendu statybos reglamentavimo gaires, atsižvelgiant i Lietuvos kraštovaizdžio savitumus ir vizualines charakteristikas. Siūlomi tokie stendu vizualinio poveikio kraštovaizdžiui vertinimo etapai: teritorijos erdvinès sandaros analizè išskiriamos vizualinès erdvès, suvokiamos iš atskiru kelio ruožų; stendų išdėstymo galimybių analizė - išskiriamos saugotinos nuo stendu statybos vizualinès erdvès ir erdvès, kuriose galima stendų lokalizacija; galimo stendu vizualinio kontrasto laipsnio su kontekstine aplinka nustatymas ir stendo vietos vizualinėje erdveje, stilistikos ir kontrasto pobūdžio su aplinka nustatymas, remiantis identiteto indekso teorija ir vizualinès erdvès vertinimu pagal i̇vairovès, kompozicinio harmoningumo, sudètingumo, išraiškingumo, prasmingumo ir kitus vizualinės kokybès kriterijus.
\end{abstract}

